\title{
A SCIENTOMETRIC REVIEW ON LEUCISM IN WILD DOLPHINS
}

\author{
Rachel Ann Hauser-Davis ${ }^{1,2 *(D)}$, Leila S. Lemos 2,3(D), Sérgio C. Moreira 2,4,5(D), Salvatore Siciliano 2,6(D) \\ ${ }^{1}$ Laboratório de Avaliação e Promoção da Saúde Ambiental, Instituto Oswaldo Cruz/Fiocruz, Rio de Janeiro, RJ, Brazil \\ ${ }^{2}$ Grupo de Estudos de Mamíferos Marinhos da Região dos Lagos (GEMM-Lagos), Praia Seca, Araruama, RJ, Brazil \\ ${ }^{3}$ Marine Mammal Institute, Hatfield Marine Science Center, Oregon State University, SE Marine Science Dr, \\ Newport, OR, USA \\ ${ }^{4}$ Setor de Mastozoologia, Departamento de Vertebrados, Museu Nacional/UFRJ, Rio de Janeiro, RJ, Brazil \\ ${ }^{5}$ Laboratório de Bioacústica e Ecologia de Cetáceos (LBEC) \\ ${ }^{6}$ Laboratório de Biodiversidade, Instituto Oswaldo Cruz/Fiocruz, Rio de Janeiro, RJ, Brazil \\ *corresponding author: rachel.hauser.davis@gmail.com ; rachel.davis@ioc.fiocruz.br
}

\begin{abstract}
RESUMO
O leucismo, uma categoria de albinismo parcial, tem sido observado em vários mamíferos marinhos, incluindo cetáceos. As mutações subjacentes, no entanto, ainda não foram identificadas, e uma grave lacuna de conhecimento sobre essa condição nesses animais foi observada. Neste contexto, o presente estudo realizou uma revisão baseada em cienciometria acerca de leucismo em golfinhos, avaliando a distribuição de casos confirmados ao redor do mundo. Registros variaram de 1929 a 2019, com um total de apenas 14 registros de casos confirmados de leucismo obtidos na literatura. Este número extremamente baixo de registros confirma a significativa lacuna de conhecimento do leucismo em golfinhos, dificultando discussões e percepções adicionais sobre as implicações ecológicas e fisiológicas dessa condição. Todos os registros relatam avistamentos de golfinhos leucísticos no hemisfério norte, exceto um, no sudeste do Brasil. As causas potenciais dessa condição são discutidas para as populações investigadas, e o papel da ciência cidadã é destacado como uma ferramenta potencial para obter mais informações sobre o assunto.
\end{abstract}

Palavras-chaves: Albinismo; Coloração anormal; Cetáceo; Análise cienciométrica; Avistamentos de golfinhos.

\begin{abstract}
Leucism, a category of partial albinism, has been observed in several marine mammals, including cetaceans. The underlying mutations, however, have not yet been identified, and a severe knowledge gap concerning this condition in these animals, has, therefore, been noted. In this context, the present study performed a scientometric-based review on leucism in dolphins, assessing the distribution of confirmed cases worldwide. Reports ranged from 1929 to 2019, with a total of only 14 records on confirmed leucism cases obtained from the literature. This extremely low number of records confirms the significant knowledge gap for leucism in dolphins, hindering further discussions and insights into the ecological and physiological implications of this condition. All records report on leucistic dolphin sightings in the northern hemisphere, except for one, in southeastern Brazil. The potential causes of this condition are discussed for the investigated populations, and the role of citizen science is highlighted as a potential tool to obtain further information on the subject.

Keywords: Albinism; Abnormal coloration; Cetacean; Scienciometric analysis; Dolphin sightings.
\end{abstract}

\section{INTRODUCTION}

Excessive or deficient melanin synthesis in vertebrates leads to atypical coloration in ectodermderived tissues, such as skin, fur or plumage, resulting in albinism, from the Latin albus, meaning "white" (Camargo et al., 2014; Federico \& Krishnamurthy, 2020). This condition is rare and can be classified as either partial or total (Alaja \& Mikkola, 1997). Total albinism comprises several specific characteristics, mostly atypical coloration in skin, hair, nails and eyes (Federico \& Krishnamurthy, 2020), whereas one particular category of partial albinism, leucism, presents white skin coloring but typical eye and nail coloration (Tonay et al., 2012).

The gene most likely responsible for leucism has been identified as the MC1R gene, which encodes the melanocortin 1 receptor protein (MC1R), 
which regulates pigment production (Bried \& Haubreux, 2000; Peters et al., 2016) by encoding the receptor protein for melanocyte-stimulating hormone (MSH). Mutations in the MC1R gene can alter this receptor's activity, either over- or under-expressing it (Kopaliani, Gurielidze \& Ninua, 2017). Constitutively active MC1R gene alleles are dominantly expressed, resulting in dark pigmentation, while inactive (dysfunctional) MC1R gene alleles are recessive and result in light or no pigmentation (Robbins et al., 1993; Fontanesi et al., 2006; Peters et al., 2016). For example, increased basal MC1R levels result in increased expression of several melanogenesis-related genes, such as tyrosinase, tyrosinase-related protein 1 , and microphthalmiaassociated transcription factor, among others, increasing eumelanin synthesis (Nishimura, 2011).

Mutations in the MC1R gene associated to pigmentation alterations have been noted in humans and several domestic animals, such as pigs, cows, chickens, horses and dogs (Peters et al., 2016) (and references therein) and in wild animal populations, in ca. 20 species comprising three mammalian orders, five avian orders, and lizards (Hoekstra, 2006). However, the genetic polymorphisms responsible for different color morphs, including leucism, have not yet been elucidated in many wild vertebrate species (Peters et al., 2016). For example, hypopigmentation cases, including leucism, have been observed in several marine mammals, including 25 cetacean species (Acevedo et al., 2009) and seven pinniped species (Peters et al., 2016), but the underlying mutations have not yet been identified (Peters et al., 2016).

It has been hypothesized that hypopigmentation may result in several negative effects, such as higher predation rates (Sandoval-Castillo et al., 2006; Acevedo, Aguayo-Lobo \& Torres, 2009); increased sun sensitivity; reduced heat absorption, decreased mating success or inbreeding (Fertl \& Rosel, 2009; Keener et al., 2011; Prado-Martinez et al., 2013; Robinson \& Haskins, 2013; Peters et al., 2016). However, other studies have indicated that a higher than normal frequency of unusually colored individuals is not associated to negative consequences in a specific habitat (Kopaliani, Gurielidze \& Ninua, 2017; Sokos et al., 2018).

Some assessments indicate that environmental factors may play a role in leucism, such as low-quality habitat, low-quality diets (Owen \& Skimmings, 1992; Peles, Lucas \& Barrett, 1995) or environmental pollution (Yauk \& Quinn, 1996; Ellegren et al., 1997; Møller \& Mousseau, 2001). Furthermore, some studies speculate that hypopigmentation cases have become more common due to climate change, although studies are still severely lacking for marine mammals (Forcada \& Hoffman, 2014; Mikkola, 2017). A severe knowledge gap concerning hypopigmentation in cetaceans, has, therefore, been noted in the literature (Fertl et al., 2004). In this context, the present study aimed to perform a scientometric-based review on leucism in dolphins, assessing the distribution of confirmed cases worldwide and carry out a discussion of potential causes of this condition.

\section{MATERIAL AND METHODS}

The scientometric technique was applied to generate qualified information on leucism in dolphins from scientific publications indexed on the Google Scholar, Pubmed and Scopus (Elsevier) scientific databases. This technique is applied in the mapping of diverse scientific fields to identify the current state of research in certain areas and allow researchers to identify and undertake new lines of research (Battisti and Salini, 2013).

After manual screening of titles and abstracts and excluding duplicates and articles that did not report leucism data, a total of 14 records were selected and included in the final quantitative analyses. Citations within the reports were also investigated and added when adequate. During a second screening, all selected articles were thoroughly read and, those matching the following selection criteria, were included. Records that did not state eye color, that reported only "anomalous color patterns" or those assessing captive animals with no capture location data were excluded. Table 1 depicts the scientometric search strategy applied herein.

Table 1. Applied scientometric search strategy concerning leucism in dolphins applied in the present study.

\section{Scientometric search strategy}

Subject

Leucism reports in dolphins

Google Scholar (Google),

Scientific databases Pubmed (NCBI), Scopus (E1sevier)

Descriptors and Leucis* AND dolphin; leucism

Boolean operators AND dolphin

Language English

Document types All types of reports except personal communications

Research areas All research areas

Timespan All years 


\section{RESULTS}

A total of 172 results were found for the search comprising the terms "leucis*" AND "dolphin", while a total of 61 results were found for the search comprising the terms "leucism" AND "dolphin". After manually reading all papers and excluding those not dealing with leucism, a total of 14 reporting confirmed leucistic cases in dolphins were included in the final quantitative analyses (Table 2). This low amount of hits obtained in the scientometric search and selection indicate that leucism reports in dolphins are extremely scarce.

Most reports were on white harbour porpoises (Phocoena phocoena) $(\mathrm{N}=9,64.2 \%)$, followed by Atlantic spotted dolphins (Stenella frontalis) $(\mathrm{N}=2$, 14.2\%) and bottlenose dolphins (Tursiops truncatus) $(\mathrm{N}=1,7.1 \%)$, short-beaked common dolphins (Delphinus delphis) $(\mathrm{N}=1,7.1 \%)$ and Risso's dolphins (Grampus griseus) (N=1, 7.1\%).

The coordinates of each sighting were plotted on a map (Figure 1). All sightings occurred in the Northern hemisphere, except for one case in Brazil.

Table 2. Articles reporting confirmed leucistic dolphins in the scientific literature worldwide.

\begin{tabular}{|c|c|c|c|}
\hline $\begin{array}{l}\text { Paper } \\
\text { ID }\end{array}$ & Title & $\begin{array}{c}\text { Publication } \\
\text { year }\end{array}$ & Authors \\
\hline 1 & $\begin{array}{l}\text { First leucistic Bottlenose Dolphin (Tursiops truncatus) } \\
\text { sighting registered in the Gulf of California, Mexico }\end{array}$ & 2019 & Perez-Puig et al \\
\hline 2 & $\begin{array}{l}\text { Rough-Toothed Dolphins (Steno bredanensis) along } \\
\text { Southeastern Brazil: Report of an anomalous pigmented } \\
\text { juvenile and description of social and feeding behaviors }\end{array}$ & 2019 & Cardoso et al. \\
\hline 3 & $\begin{array}{l}\text { Records of harbour porpoise (Phocoena phocoena) in the } \\
\text { mouth of the Douro River (Northern Portugal) with presence } \\
\text { of an anomalous white individual }\end{array}$ & 2019 & Gil et al. \\
\hline 4 & $\begin{array}{l}\text { Records of anomalously white harbour porpoises and } \\
\text { atypical pigmented short-beaked common dolphin in the } \\
\text { Georgian Black Sea Waters }\end{array}$ & 2017 & Kopaliani et al. \\
\hline 5 & $\begin{array}{l}\text { Rare records of hypo- and hyper-pigmented individuals in } \\
\text { two delphinid species off Madeira Island }\end{array}$ & 2017 & Alves et al. \\
\hline 6 & $\begin{array}{l}\text { Three Cases of Anomalously White Risso's } \\
\text { Dolphins Grampus griseus in Japan }\end{array}$ & 2017 & Funasaka et al. \\
\hline 7 & $\begin{array}{l}\text { Anomalously White Atlantic Spotted Dolphins (Stenella } \\
\text { frontalis, Cuvier, 1892) Off the Azores }\end{array}$ & 2016 & dos Santos, et al. \\
\hline 8 & $\begin{array}{l}\text { Rare sighting of an anomalously white harbour porpoise } \\
\text { (Phocoena phocoena) in the Moray Firth, north-east } \\
\text { Scotland }\end{array}$ & 2013 & $\begin{array}{l}\text { Robinson and } \\
\text { Haskins }\end{array}$ \\
\hline 9 & $\begin{array}{l}\text { First records of anomalously white harbour porpoises } \\
\text { (Phocoena phocoena) in the Turkish seas with a global } \\
\text { review }\end{array}$ & 2012 & Tonay et al. \\
\hline 10 & $\begin{array}{l}\text { First records of anomalously white Harbor Porpoises } \\
\text { (Phocoena phocoena) from the Pacific Ocean }\end{array}$ & 2011 & Keener et al. \\
\hline 11 & $\begin{array}{l}\text { Mammals of the Black Sea and the Sea of Azov. Results } \\
\text { of joint biological-commercial dolphin whaling studies } \\
\text { [Translated from Russian by the Translation Bureau } \\
\text { Multilingual Services Division Department of the Secretary } \\
\text { of State of Canada, 1978] }\end{array}$ & 1956 & Kleinenberg \\
\hline 12 & $\begin{array}{l}\text { Über einem weißen Tümmler [On a Bottlenose Dolphin, in } \\
\text { German] }\end{array}$ & 1929 & Peters \\
\hline 13 & Some rare cases of albinism in animals & 1913 & Prince \\
\hline 14 & On a white porpoise & 1912 & Mcintosh \\
\hline
\end{tabular}




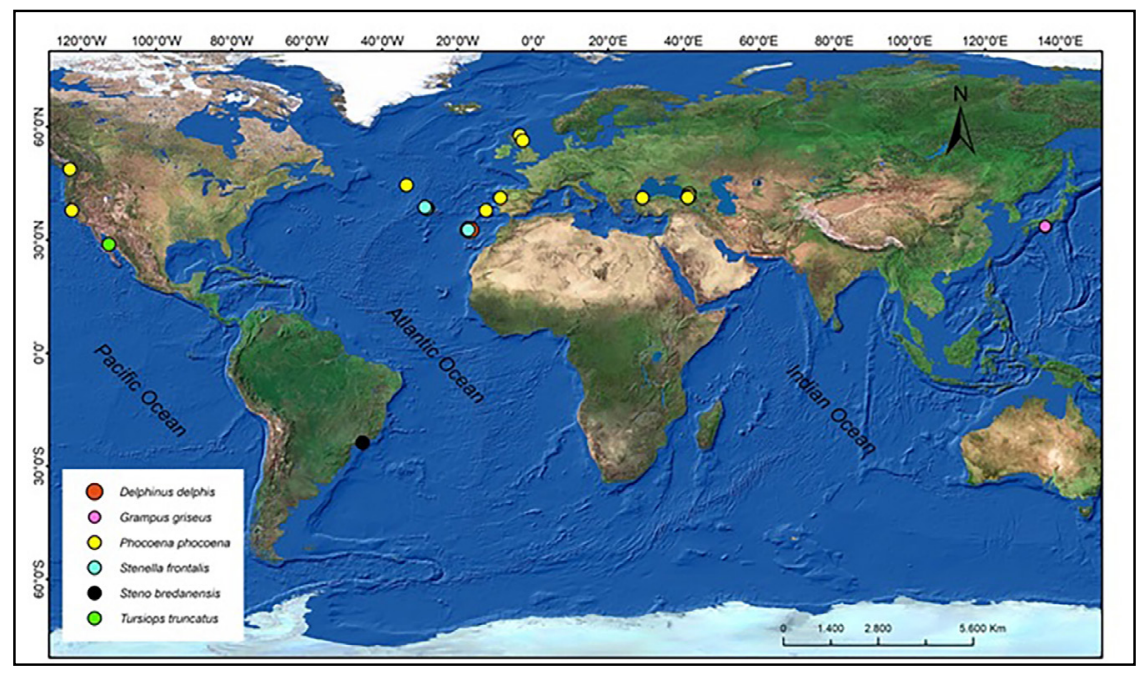

Figure 1. Plotted coordinates of each confirmed leucistic dolphin sightings around the globe reported in the literature.

Concerning maturity, only one of the articles recorded a calf, while the others reported both juvenile and adult specimens, and two did not state this information. Data on species and maturity for each of the reported individuals of the 14 assessed studies are shown in Table 3.

\section{DISCUSSION}

Several negative leucism effects have been postulated, such as reduced countershading, in turn increasing detection by predators or prey species and prey avoidance (Sandoval-Castillo, MarianoMeléndez \& Villavicencio-Garayzar, 2006; Acevedo, Aguayo-Lobo \& Torres, 2009); increased chances of sunburn or skin cancer; reduced heat absorption, leading to thermoregulatory limitations in cold waters, reduced attractiveness to the opposite sex, leading to decreased mating success, or inbreeding, since some assessments in mammals have reported a possible link between coloration and inbreeding, where affected individuals could be at a fitness disadvantage due to inbreeding depression (Fertl \& Rosel, 2009; Keener et al., 2011; Prado-Martinez et al., 2013; Robinson \& Haskins, 2013; Peters et al., 2016).

However, both juvenile and adults were reported in the 14 articles investigated herein. This corroborates several previous assessments in marine mammals, indicating evident survival and relative longevity of leucistic individuals (Forestell et al., 2001; Tonay et al., 2012; Robinson \& Haskins, 2013; Gil et al., 2019), both male and females, in line with studies indicating no associations to negative consequences in a specific habitat for several species (Abreu et al., 2013; Kopaliani et al., 2017). For example, Antarctic fur seals (Arctocephalus gazella) from Bird Island, South Georgia, displaying hypopigmentation attributed to leucism were identified as homozygous for a nonsynonymous mutation within the MC1R gene.This results in the substitution of serine with phenylalanine at an evolutionarily highly conserved structural domain. In the aforementioned study, both wildtype and hypopigmented individuals did not differ significantly in their standardized multilocus MC1R heterozygosity (which would otherwise be indicative of low genome-wide heterozygosity) (Peters et al., 2016). The authors, thus, indicate that this lack of association implies that hypopigmented individuals are unlikely to suffer disproportionately from inbreeding depression, and are, therefore, are not at a selective disadvantage in the wider population in this context. In another assessment, leucism in bats did not seem to negatively affect their reproductive potential, as leucistic pregnant females and males in reproductive conditions have been reported in the literature (García-Morales et al., 2013). Although studies in dolphins are scarce, the fact that adult dolphins of a reproductive age were reported in most of the reports seems to indicate that a leucistic condition does not negatively affect dolphin survival, although further studies are required in this regard.

Comparatively, a high number of leucistic dolphin have been sighted in the Black Sea, even considering only confirmed leucistic cases. This has been commented on in previous assessments (Kopaliani, Gurielidze \& Ninua, 2017), with regard 
Table 3. Species and maturity data for each of the 14 leucistic dolphin cases reported in the scientific literature worldwide.

\begin{tabular}{|c|c|c|c|}
\hline Paper ID & Species & Common name & Maturity \\
\hline 1 & Phocoena phocoena & White harbour porpoise & $\begin{array}{l}\text { Calf* } \\
\text { Calf* } \\
\text { N.A. }\end{array}$ \\
\hline 2 & Tursiops truncatus & Bottlenose dolphin & Subadult \\
\hline 3 & Stenella frontalis & $\begin{array}{l}\text { White Atlantic Spotted } \\
\text { dolphin }\end{array}$ & $\begin{array}{c}\text { Adult } \\
\text { Juvenile } \\
\text { Juvenile } \\
\text { Juvenile }\end{array}$ \\
\hline 4 & Delphinus delphis* & $\begin{array}{l}\text { Short-beaked common } \\
\text { dolphin }\end{array}$ & $\begin{array}{l}\text { Adult** } \\
\text { Adult** }\end{array}$ \\
\hline & Stenella frontalis & Atlantic spotted dolphin & Adult \\
\hline 5 & Grampus griseus & Risso's dolphin & $\begin{array}{c}\text { Adult } \\
\text { Juvenile } \\
\text { Juvenile }\end{array}$ \\
\hline 6 & Steno bredanensis & Rough-Toothed dolphin & Juvenile \\
\hline 7 & Phocoena phocoena & White harbour porpoise & $\begin{array}{c}\text { Adult } \\
\text { Adult*** } \\
\text { Adult*** } \\
\text { Adult*** }\end{array}$ \\
\hline 8 & Phocoena phocoena & White harbour porpoise & Adult \\
\hline 9 & Phocoena phocoena & White harbour porpoise & Adult \\
\hline 10 & Phocoena phocoena & White harbour porpoise & $\begin{array}{l}\text { Adult } \\
\text { Adult }\end{array}$ \\
\hline 11 & Phocoena phocoena & White harbour porpoise & Juvenile \\
\hline 12 & Phocoena phocoena & White harbour porpoise & Juvenile \\
\hline 13 & Phocoena phocoena & White harbour porpoise & N.A. \\
\hline 14 & Phocoena phocoena & White harbour porpoise & Juvenile \\
\hline
\end{tabular}

Legend: * Same individual seen twice in report $1 ; * *$ Possibly the same individual seen twice in report $4 ; * * *$ Same individual seen thrice in report 7.

to different factors. These include: (i) the fact that the Black Sea harbour porpoise's population is small and isolated populations due to long-term isolation (at least 9,000 ya) (Fontaine et al., 2007, 2010, 2012) from the nearest Atlantic harbour porpoises' populations and consequent inbreeding (Kopaliani et al., 2017), with consequent loss of genetic variability, favoring the appearance of recessive alleles, increasing leucism frequency (Łopucki \& Mróz, 2011); (ii) the fact that the harbour porpoise is an apex Black Sea ecosystem predator, with no natural predators, so pigmentation would not be a protective countershading factor in this regard (Kopaliani et al., 2017); (iii) the relatively high water turbidity and limited surface light penetration would negate potential advantages of normal pigmentation (i.e. countershading) (Kopaliani et al., 2017). Therefore, the authors indicate that this high number of records of atypically pigmented dolphins may be associated with a relaxed selection pressure in this area when compared to the Mediterranean or Atlantic basins (Kopaliani et al., 2017), even though the available data is insufficient to conclude if atypically colored individuals in the Black Sea are in fact more frequent 
than in other marine basins (Kopaliani et al., 2017). Other factors, however, may be at play here, and the high sighting rates may be due to increased field efforts compared to other areas, especially the southern hemisphere, due to financial constraints, especially in developing countries (Smith \& Reeves, 2000; Smith \& Hobbs, 2002; Daura-Jorge \& SimõesLopes, 2017). These relatively frequent reports in the northern hemisphere seem to indicate that these animals seem not to display any issues regarding thermoregulatory limitations in cold waters, as temperatures in the region are lower than in many other areas around the globe.

Concerning the association between environmental factors and leucism, some reports have speculated that climate change may play a role in increased leucism frequency (Mikkola, 2017), as reported, for example, for declining fur seal populations (Forcada \& Hoffman, 2014), where this environmental variable selects for heterozygosity. Studies in this regard, however, are almost nonexistent, hampering discussions on climate change effects concerning leucism in dolphins. Regarding the role of environmental pollution, studies on birds have postulated that the higher frequency of leucistic animals in these environments compared to rural areas may be due to higher mutagen (pollution) concentrations in cities (Yauk \& Quinn, 1996; Møller \& Mousseau, 2001), while studies carried out in Chernobyl have made this same association between birds and radioactivity (Moller, 1993). In addition, low-quality habitats have also been implicated in leucism in geese (Owen \& Skimmings, 1992). Mammal assessments are, again, rare, and only one study was found associating environmental factors, i.e. low-quality diets, to leucism in mammals (voles) inhabiting high quality grassland habitat (Peles et al., 1995).

As indicated almost two decades ago (Fertl et al., 2004), a very low number of papers is found on the subject of hypopigmentation in cetaceans, even less so for leucism in particular, indicating the significant knowledge gap in this regard and hindering further discussions and insights into the ecological and physiological implications of this condition. Therefore, we recommend further monitoring efforts in this regard be carried out by both scientists and applying the concept of citizen science, which has been proven a powerful tool in cetacean studies worldwide (Embling et al., 2015; Lodi \& Tardin, 2018), especially in the southern hemisphere, which still lacks these types of assessments.

\section{ACKNOWLEDGEMENTS}

RAHD acknowledges support from Fundação Carlos Chagas Filho de Amparo à Pesquisa do Estado do Rio de Janeiro - FAPERJ). SS acknowledges support from Conselho Nacional de Desenvolvimento Científico e Tecnológico - CNPq (Produtividade em Pesquisa: 306076/2019-5) and INOVA Fiocruz.

\section{REFERENCES}

Abreu M, Machado R, Barbieri F, Freitas N, Oliveira L. 2013. Anomalous colour in Neotropical mammals: a review with new records for Didelphis sp. (Didelphidae, Didelphimorphia) and Arctocephalus australis (Otariidae, Carnivora). Braz. J. Biol. 73:185-194.

Acevedo J, Aguayo-Lobo A, Torres D. 2009. Albino Weddell seal at Cape Shirreff, Livingston Island, Antarctica. Polar Biology 32:1239-1243. DOI: 10.1007/s00300-009-0680-8.

Alaja P, Mikkola H. 1997. Albinism in the Great Gray Owl (Strix nebulosa) and other owls. In: Biology and Conservation of Owls of the Northern Hemisphere Second International Symposium. 33-37.

Alves F, Ferreira R, Dias L, Nicolau C, Sousa D, Moura C, Gomes C, Dinis A. 2017. Rare records of hypo- and hyper-pigmented individuals in two delphinid species off Madeira Island. Hystrix the Italian Journal of Mammalogy 28(1):116-118. DOI: 10.4404/hystrix-28.1-11888.

Bried J, Haubreux D. 2000. An aberrantly pigmented southern elephant seal (Mirounga leonina) at Iles Kerguelen, southern Indian Ocean. Marine Mammal Science 16:681-684. DOI: 10.1111/j.17487692.2000.tb00964.x.

Camargo I, Rios E, Cornejo-Latorre C, ÁlvarezCastañeda ST. 2014. First Record of leucism in the Genus Peromyscus (Mammalia: Rodentia). Western North American Naturalist 74:366-368. DOI: 10.3398/064.074.0301.

Cardoso J, Francisco, AF, de Souza SP, Siciliano S. 2019. Rough-Toothed dolphins (Steno bredanensis) along Southeastern Brazil: Report of an anomalous pigmented juvenile and description of social and feeding behaviors. Aquatic Mammals 45(1):30-36. DOI: 10.1578/AM.45.1.2019.30.

Daura-Jorge FG, Simões-Lopes PC. 2017. Markrecapture vs. line-transect abundance estimates of a 
coastal dolphin population: a case study of Tursiops truncatus from Laguna, southern Brazil. Latin American Journal of Aquatic Mammals 11:133-143. DOI: 10.5597/lajam00222.

De Battisti F, Salini S. 2013. Robust analysis of bibliometric data. Statistical Methods and Applications 22(2):269-83.

Dos Santos RP, Simião S, Madruga P, Mendonça AS, Seitre R, Gomes-Pereira JN. 2016. Anomalously white Atlantic Spotted Dolphins (Stenella frontalis, Cuvier, 1892) off the Azores. Aquatic Mammals 42(2):245+. DOI: 10.1578/AM.42.2.2016.245

Ellegren H, Lindgren G, Primmer CR, Møller AP. 1997. Fitness loss and germline mutations in barn swallows breeding in Chernobyl. Nature 389:593596. DOI: $10.1038 / 39303$.

Embling CB, Walters AEM, Dolman SJ. 2015. How much effort is enough? The power of citizen science to monitor trends in coastal cetacean species. Global Ecology and Conservation 3:867-877. DOI: 10.1016/j.gecco.2015.04.003.

Federico JR, Krishnamurthy K. 2020. Albinism. In: StatPearls. Treasure Island (FL): StatPearls Publishing.

Fertl D, Barros NB, Rowlett RA, Estes S, Richlen M. 2004. An update on anomalously white cetaceans, including the first account for the pantropical spotted dolphin (Stenella attenuata graffmani). Latin American Journal of Aquatic Mammals 3:163-166. DOI: $10.5597 /$ lajam00061.

Fertl D, Rosel PE. 2009. Albinism. In: Encyclopedia of Marine Mammals. 24-26. DOI: 10.1016/B978-012-373553-9.00006-7.

Fontaine MC, Baird SJE, Piry S, Ray N, Tolley KA, Duke S, Birkun AA, Ferreira M, Jauniaux T, Llavona Á, Öztürk B, Öztürk AA, Ridoux V, Rogan E, Sequeira M, Siebert U, Vikingsson GA, Bouquegneau JM, Michaux JR. 2007. Rise of oceanographic barriers in continuous populations of a cetacean: The genetic structure of harbour porpoises in Old World waters. BMC Biology 5:30. DOI: 10.1186/1741-7007-5-30.

Fontaine MC, Snirc A, Frantzis A, Koutrakis E, Oz̈türk B, Özẗurk AA, Austerlitz F. 2012. History of expansion and anthropogenic collapse in a top marine predator of the Black Sea estimated from genetic data. Proceedings of the National Academy of Sciences of the United States of America 109:25692576. DOI: 10.1073/pnas.1201258109.
Fontaine MC, Tolley KA, Michaux JR, Birkun A, Ferreira M, Jauniaux T, Llavona N, Öztürk B, Öztürk AA, Ridoux V, Rogan E, Sequeira M, Bouquegneau JM, Baird SJE. 2010. Genetic and historic evidence for climate-driven population fragmentation in a top cetacean predator: The harbour porpoises in European water. Proceedings of the Royal Society B: Biological Sciences 277:2829-2837. DOI: 10.1098/ rspb.2010.0412.

Fontanesi L, Tazzoli M, Beretti F, Russo V. 2006. Mutations in the melanocortin 1 receptor (MC1R) gene are associated with coat colours in the domestic rabbit (Oryctolagus cuniculus). Animal Genetics 37:489-493. DOI: 10.1111/j.13652052.2006.01494.x.

Forcada J, Hoffman JI. 2014. Climate change selects for heterozygosity in a declining fur seal population. Nature 511:462-465. DOI: 10.1038/nature13542.

Forestell PH, Paton DA, Hodda P, Kaufman GD. 2001. Observations of a hypo-pigmented humpback whale, Megaptera novaeangliae, off east coast Australia: 1991-2000. Memoirs of the Queensland Museum 47:437-450.

Funasaka N, Kirihata T, Hosono M, Kato H, Ohsumi S. 2017. Three Cases of Anomalously White Risso's Dolphins Grampus griseus in Japan. Mammal Study 42(3):173-178. DOI: $10.3106 / 041.042 .0307$

García-Morales R, Rojas-Martínez AE, Gómez ESA, Moreno CE. 2013. Leucism in the giant fruiteating bat (Artibeus lituratus Olfers, 1818) in the state of Hidalgo, Mexico. Chiroptera Neotropical 19:1212-1215.

Gil Á, Correia AM, Sousa-Pinto I. 2019. Records of harbour porpoise (Phocoena phocoena) in the mouth of the Douro River (northern Portugal) with presence of an anomalous white individual. Marine Biodiversity Records 12:1-5. DOI: 10.1186/s41200018-0160-3.

Hoekstra HE. 2006. Genetics, development and evolution of adaptive pigmentation in vertebrates. Heredity 97:222-234. DOI: 10.1038/sj.hdy.6800861.

Keener W, Szczepaniak I, Adam Ü, Webber M, Stern J. 2011. First record of anomalously white harbor porpoises (Phocoena phocoena) from the Pacific Ocean. Journal of Marine Animals and Their Ecology 4:19-24.

Kleinenberg SE. 1956. Mammals of the Black Sea and the Sea of Azov. Results of joint biologicalcommercial dolphin whaling studies [Translated 
from Russian by the Translation Bureau Multilingual Services Division Department of the Secretary of State of Canada, 1978]. Results of joint biologicalcommercial dolphin whaling studies. USSR Academy of Sciences Press, Moscow. 287 pp.

Kopaliani N, Gurielidze Z, Ninua L. 2017. Records of anomalously white harbour porpoises and atypical pigmented short-beaked common dolphin in the Georgian Black Sea waters. J. Black Seal Mediterranean Environment 23:66-74.

Lodi L, Tardin R. 2018. Citizen science contributes to the understanding of the occurrence and distribution of cetaceans in southeastern Brazil - A case study. Ocean and Coastal Management 158:45-55. DOI: 10.1016/j.ocecoaman.2018.03.029.

Łopucki R, Mróz I. 2011. Cases of colouration anomalies in small mammals of Poland, and reasons for their incidence. Annales UMCS, Biologia 65:6776. DOI: 10.2478/v10067-011-0006-4.

Mcintosh WD. 1912. On a white porpoise. Notes from the Gatty Marine Laboratory, St. Andrews, No. 33. Annals and Magazine of Natural History 10: 117-119.

Mikkola H. 2017. Owls of the world: A photographic guide, Second Edition. London: Bloomsbury Publishing.

Moller AP. 1993. Morphology and sexual selection in the barn swallow Hirundo rustica in Chernobyl, Ukraine. Proceedings of the Royal Society B: Biological Sciences 252:51-57. DOI: 10.1098/ rspb.1993.0045.

Møller AP, Mousseau TA. 2001. Albinism and phenotype of barn swallows (Hirundo rustica) from Chernobyl. Evolution 55:2097-2104. DOI: 10.1111/j.0014-3820.2001.tb01324.x.

Nishimura EK. 2011. Melanocyte stem cells: A melanocyte reservoir in hair follicles for hair and skin pigmentation. Pigment Cell and Melanoma Research 24:401-410. DOI: 10.1111/j.1755148X.2011.00855.x.

Owen M, Skimmings P. 1992. The occurrence and performance of leucistic Barnacle Geese Branta leucopsis. Ibis 134:22-26. DOI: 10.1111/j.1474919X.1992.tb07224.x.

Peles JD, Lucas MF, Barrett GW. 1995. Population Dynamics of Agouti and Albino Meadow Voles in High-Quality, Grassland Habitats. Journal of Mammalogy 76:1013-1019. DOI: 10.2307/1382595.
Perez-Puig H, Heckel G, Meltzer L. 2019. First leucistic Bottlenose Dolphin (Tursiops truncatus) sighting registered in the Gulf of California, Mexico. Aquatic Mammals 45(5): 507-512. DOI: 10.1578/ AM.45.5.2019.507.

Peters N. 1929. Über einem weißen Tümmler [On a Bottlenose Dolphin, in German]. Der Fisherbote 22:354- 355 .

Peters L, Humble E, Kröcker N, Fuchs B, Forcada J, Hoffman JI. 2016. Born blonde: a recessive lossof-function mutation in the melanocortin 1 receptor is associated with cream coat coloration in Antarctic fur seals. Ecology and Evolution 6:5705-5717. DOI: 10.1002/ece3.2290.

Prado-Martinez J, Hernando-Herraez I, LorenteGaldos B, Dabad M, Ramirez O, Baeza-Delgado C, Morcillo-Suarez C, Alkan C, Hormozdiari F, Raineri E, Estellé J, Fernandez-Callejo M, Valles M, Ritscher L, Schöneberg T, de la Calle-Mustienes E, Casillas S, Rubio-Acero R, Melé M, Engelken J, Caceres M, Gomez-Skarmeta JL, Gut M, Bertranpetit J, Gut IG, Abello T, Eichler EE, Mingarro I, Lalueza-Fox C, Navarro A, Marques-Bonet T. 2013. The genome sequencing of an albino Western lowland gorilla reveals inbreeding in the wild. BMC Genomics 14:1-8. DOI: 10.1186/1471-2164-14-363.

Prince EE. 1913. Some rare cases of albinism in animals. The Ottawa Naturalist, Bd. 27.

Robbins LS, Nadeau JH, Johnson KR, Kelly MA, Roselli-Rehfuss L, Baack E, Mountjoy KG, Cone RD. 1993. Pigmentation phenotypes of variant extension locus alleles result from point mutations that alter MSH receptor function. Cell 72:827-824. DOI: 10.1016/0092-8674(93)90572-8.

Robinson KP, Haskins GN. 2013. Rare sighting of an anomalously white harbour porpoise (Phocoena phocoena) in the Moray Firth, north-east Scotland. Marine Biodiversity Records 6:1-3. DOI: 10.1017/ S1755267212001339.

Sandoval-Castillo J, Mariano-Meléndez E, Villavicencio-Garayzar CJ. 2006. New record of albinism in elasmobranch fishes: The tiger shark Galeocerdo cuvier and the Pacific electric ray Narcine entemedor. Cybium 30:191-192.

Smith BD, Hobbs L. 2002. Status of Irrawaddy dolphins Orcaella brevirostris in the upper reaches of the Ayeyarwady River, Myanmar. Raffles Bulletin of Zoology Supplement:67-73.

Smith BD, Reeves RR. 2000. Report of the second 
meeting of the Asian river dolphin committee, 22-24 February 1997, Rajendrapur, Bangladesh. Pp.1-14. In: Reeves RR, Smith BD, Kasuya T eds. Biology and Conservation of Freshwater Cetaceans in Asia.

Sokos C, Kollaris N, Papaspyropoulos KG, Poirazidis K, Birtsas P. 2018. Frequency of abnormalities in wildlife species: is there a relation with their ecology? Zoology and Ecology 28:389-394. DOI: 10.1080/21658005.2018.1537905.

Tonay AM, Bilgin S, Dede A, Akkaya A, Yeşilçiçek T,
Köse Ö, Ceylan Y. 2012. First records of anomalously white harbour porpoises (Phocoena phocoena) in the Turkish seas with a global review. Hystrix 23:1-11. DOI: 10.4404/hystrix-23.2-4792.

Yauk CL, Quinn JS. 1996. Multilocus DNA fingerprinting reveals high rate of heritable genetic mutation in herring gulls nesting in an industrialized urban site. Proceedings of the National Academy of Sciences of the United States of America 93:1213712141. DOI: $10.1073 /$ pnas.93.22.12137. 